\title{
The Analysis of Financial Performance to Capital Structure
}

\author{
Berlian Karlina \\ Universitas Budi Luhur, DKI Jakarta 12260, Indonesia
}

\begin{abstract}
A B S T R A C T
Capital structure is very important to analyze the company sustainability in finance aspect. Establishing capital structures need to consider some variables that may the company's condition in determining ability of the company to endure and develop company's financial performance. This study was aimed to examine the effect of profitability, liquidity, company size and asset structure on capital structure at company of large trade sub sectors of production and consumer goods in Indonesia Stock Exchange (IDX) in year 20142018. The sampling technique used in this study was purposive sampling; the number of samples used was 9 companies from a population of 28 companies. Analytical tool used in this study is multiple linear regression assisted by SPSS version 20.0 programs with enter methods. Results of this study indicate that the profitability, liquidity and asset structure are negatively and significantly affected by the capital structure while the company size has a positive and significant effect on capital structure.
\end{abstract}

AR T I C LE IN F O

Article History:

Received : 23-06-2020

Revised : 08-01-2021

Accepted : 09-01-2021

Published : 15-02-2021

Keywords:

Profitability

Liquidity

Company Size

Asset Structure

*Corresponding Author E-mail:

berlian.karlina@budiluhur.ac.id

Copyright (C) 2021 Authors. This is an open access article distributed under the Creative Commons Attribution License (CC-BY-SA 4.0) which permits use, distribution and reproduction in any medium, provided the original work is properly cited \& ShareAlike terms followed.

\section{INTRODUCTION}

Competition between companies that increase very tight causes companies to be encouraged to improve the company's financial performance. Company needs capital to carry out operations and business development. Capital structure is a comparison between foreign capital and own capital (Riyanto, 2001). By strengthening the capital structure, company will have an increasingly greater access to obtaining funding from banks and other funding variations.
Capital structure policy in a company is the thing that should be properly considered as much as possible to fit the needs of the company, let alone the company of the large trade sub sectors of production goods and certainly requires a very large funding system in running the company's performance on business competition. Companies in this sector have a high growth rate so that it should provide sufficient capital for the opening of business and development of its businesses. 
With this phenomenon we will re-analyze by implementing some ratio of the company to know how much impact of each ratio. Based on the background description described above, the author chose the title "influence of profitability, liquidity, company size and asset structure to capital structure (empirical study of large trade sub-sector companies of production goods and consumer goods in the Indonesia Stock Exchange period 2014-2018)".

\section{LITERATURE REVIEW}

Many theories and concepts relate to the discussion and research the problem, the various perspectives and the solving of such theories need to be implemented into certain related practices and cases. There are two theories of capital structure that aims to give the foundation of thinking to know the optimal structure of capital in this study, that is;

a. Balancing Theories

Balancing Theories, according to Fahmi (2017) is a policy taken by the company to find additional funds by looking for loans to the banking or also by issuing bonds (bonds), the implementation of balancing Theories is also possible to be applied by a government is to make loans from foreigners such as foreign governments or also to international donor agencies such as World Bank, International Monetery Found, Asian Development Bank and etc.

b. Pecking Order Theory

Pecking order theory stated that the company liked internal financial (funding from the company's operating results tangible profit balance). If the external financing is required, the company will issue the safest securities first, which is initiated by debt, then followed by securities with characteristic options, if not enough new shares will be issued (Nanda and Retnani, 2017).

\section{Capital Structure}

Hartijo and Martono (2013), stated that the capital structure is a long-term financing comparison of the company, which is indicated by a ratio of long-term debt to its own capital. In other words, this ratio serves to know every rupiahs of its own capital which is used for debt assurance. The capital structure in this study was proscribed with a debt to equity ratio (DER).

$$
\text { Debt to Equity Ratio }=\frac{\text { Total Debt }}{\text { Equity }}
$$

\section{Profitability}

Profitability is ratio to measure company's ability to generate profit from its normal business activities (Hery, 2015). Some ratios are commonly used in measuring profitability i.e. ROA, ROE and ROI.

Return On Asset $(R O A)=E A T$

\section{Liquidity}

Liquidity indicates that the company's ability to fulfill its financial obligations must be fulfilled or the company's ability to fulfill the monetary obligation at the time of invoiced (Munawir in Satriana, 2017:18). Current Ratio is one of ratios to measure company's ability to fulfill short-term obligations without facing any difficulties.

$$
\text { Current Ratio }=\frac{\text { Current Assets }}{\text { Current Liabilities }}
$$

\section{Company Size}

Company Size is the condition of a large company that will be easier to obtain the capital in the market compared with small companies. Because such ease of access, large companies have greater flexibility (Sartono, 2015).

$$
\text { Company Size }=\text { LN (Total Assets) }
$$

\section{Asset Structure}

Asset Structure is a relative composition of fixed assets owned by the company (Tangiduk et al., 2017), it can be said the asset structure can be used to determine how much longterm debt can be taken and this will affect the determination of 
the magnitude the capital structure.

$$
\text { Asset Structure }=\frac{\text { Fixed Assets }}{\text { Total Assets }}
$$

\section{RESEARCH METHOD}

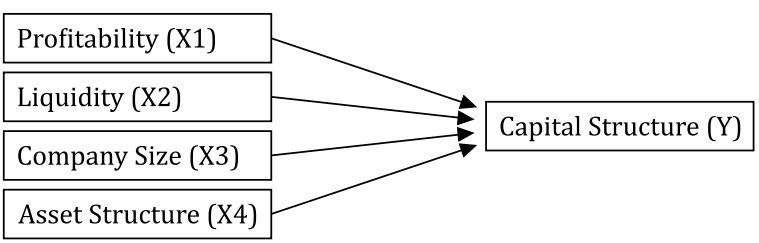

Figure 1. Research Framework

Profitability is the ability of a company to gain profit during specified period of time. By having a high level of profitability, the company is categorized more independent when compared to companies that have low profitability (Gunadhi and Putra, 2019).

H1: Profitability of significant effect on capital structure.

Liquidity is the ratio that shows the relationship of cash and other current assets with a smooth obligation in financial performance. So it can be assumed that the current ratio affects the capital structure. It can be explained that if the ratio value is low, the company undertakes to pay the debt (cashmere, 2018).

H2: Liquidity of significant impact on capital structure

Company size often used as an indicator for the possibility of bankruptcy for a company, where larger companies are seen more capable of facing a crisis in running its business. This will make it easier for companies with large size to obtain loans from creditors because they have more capability in managing their financial performance of business.

H3: Company size significant effect on capital structure

Companies whose assets or activities have a comparison of long-term fixed assets are more likely to use more long-term debt due to existing fixed assets that can be used as debt collateral. This the asset structure can be used to determine how much long-term debt can be taken and this will affect the determination of the magnitude of the capital structure.

H4: Asset structure significant influence on capital structure

The research used a secondary data with a capital structure (DER) as dependent variables and independent variables consisting of profitability (ROA), Liquidity (CR), company size, asset structure. The population in this research is a large trading sub-sector company of production goods and consumer goods listed on the Indonesia Stock Exchange (IDX) period 2014 to 2018 which amounted to 28 companies with sampling method purposive sampling based on predefined criteria so that 9 companies can be obtained as a sample. The limited criteria specified in sampling are:

1. It is a large trading company sub-sector of production goods and consumer goods listed on Indonesia Stock Exchange period 2014 2018.

2. In presenting the financial report of the company sub-sector of large trade of production goods and consumer goods using the value of rupiah in the Indonesian stock exchange for 2014-2018.

3. The company has a large trade sub-sector of production goods and consumer goods in presenting a complete financial report that always ends on December $31^{\text {st }}$ every year.

Techniques for analyzing data using multiple linear regression with the help of SPSS statistical data program version 20.0 and Microsoft Excel 2010. The technique is done in order to know the relationship of free variables with its variables so that the result of multiple linear analysis is expressed as follows:

$\mathrm{DER}=\alpha+\beta 1 \mathrm{ROA} \beta 2 \mathrm{CR}+\beta 3 \mathrm{UP}+\beta 4 \mathrm{SA}+\mathrm{e}$
DER
: Capital Structure
a : Constant
$\beta 1, \beta 2, \beta 3, \beta 4 \quad$ : Regression Coefficient 
Table 1. Criteria Research

\begin{tabular}{cl}
\hline No & Criteria \\
\hline 1 & $\begin{array}{l}\text { It is a large trading company sub-sector of production goods and consumer goods listed on Indonesia Stock Exchange } \\
\text { period 2014 - 2018. }\end{array}$ \\
\hline 2 & $\begin{array}{l}\text { The company has a large trade sub-sector of production goods and consumer goods in did not presenting a complete } \\
\text { financial report that always ends on December 31st every year. }\end{array}$ \\
\hline 3 & $\begin{array}{l}\text { In presenting the financial report of the company sub-sector of large trade of production goods and consumer goods } \\
\text { do not using the value of rupiah in the Indonesian stock exchange for 2014-2018. }\end{array}$ \\
\hline & Total \\
\hline
\end{tabular}

$\begin{array}{ll}\text { ROA } & \text { : Profitability } \\ \text { CR } & \text { : Liquidity } \\ \text { UP } & : \text { Company size } \\ \text { SA } & : \text { Asset Structure } \\ \text { e } & : \text { Error }\end{array}$

\section{RESULT AND DISCUSSION}

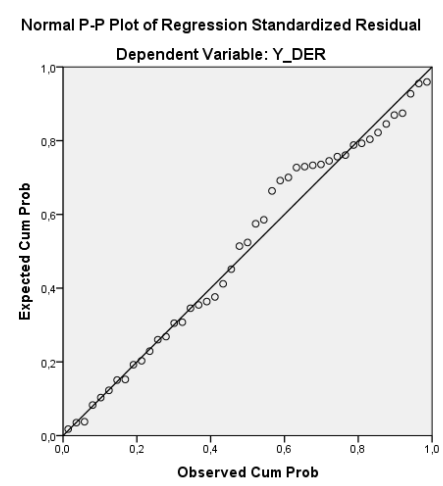

Figure 2. P-Plot Graph

Source: Output IBM SPSS 20.0

The P-Plot Graph used to know whether the population of distributed data is normal or not. It can be seen from the above diagonal chart, if most of the dots are very close to the line or even attached to the line, then the data can be concluded assuming the normality.
From the image P-Plot Graph visible data spread around and follow the direction of the diagonal line, then the data used is normal distribution and regression model has fulfilled the assumption of normality.

\section{Multicolinearity Test}

Multicolinearity testing is performed to determine if the free variables are correlated. A good regression Model should not occur in correlation between independent variables. Multicolinearity test is performed by looking at the value of variance inflation factor (VIF). If the value of VIF is $\geq 10$, it can be said there is a symptom of multicolinearity and if the value of VIF of $<10$ Then there is no symptom of multicolinearity. The following data processing results table for multicholinerity test.

The test results of multicolinearity in above table, can be seen the value of VIF and Tolerance in the regression model in test ie the output of each independent variable ROA, CR, UP and SA have the value of VIF $1.388,1.358,1.975 \& 1.260<$ 10 and the value of Tolerance $0.721,0.736,0.506$, $0.794>0.1$. From the results of the test output

Table 2. Statistical Coefficient Test

\begin{tabular}{|c|c|c|c|c|c|c|c|c|}
\hline \multicolumn{2}{|c|}{ Model } & \multicolumn{2}{|c|}{$\begin{array}{l}\text { Unstandardized } \\
\text { Coefficients }\end{array}$} & \multirow{2}{*}{$\begin{array}{c}\text { Standardized } \\
\text { Coefficients } \\
\text { Beta } \\
\end{array}$} & \multirow[t]{2}{*}{$\mathbf{t}$} & \multirow[t]{2}{*}{ sig. } & \multicolumn{2}{|c|}{$\begin{array}{c}\text { Collinearity } \\
\text { Statistics }\end{array}$} \\
\hline & & B & Std. Error & & & & Tolerance & VIF \\
\hline \multirow{5}{*}{1} & (Constant) & $-1,647$ & 1,774 & &,- 928 & ,359 & & \\
\hline & X1_ROA & $-32,342$ & 4,765 &,- 753 & $-6,787$ & ,000 & ,721 & 1,388 \\
\hline & $\mathrm{X} 2$ _CR &,- 053 & ,017 &,- 335 & $-3,050$ & ,004 & ,736 & 1,358 \\
\hline & X3_UP & 200 & ,067 & ,394 & 2,979 & ,005 & ,506 & 1,975 \\
\hline & X4_SA & $-2,818$ & ,675 & -,441 & $-4,173$ & ,000 & ,794 & 1,260 \\
\hline
\end{tabular}

Source: Output IBM SPSS 20.0 
can be stated there is no correlation between the independent variables, then the model can be used for research.

\section{Heteroscedasticity Test}

Heteroscedasticity can be analyzed by looking at the scatterplots chart, i.e. if the dots form a particular pattern that is orderly (wavy then widens and narrowed, shrink then enlarged or otherwise) then there has been heteroscedasticity, otherwise if the dots are not forming a certain pattern then it does not occur heteroscedasticity.

From Image Scatterplot graph, it appears that the dots ' spread does not form a specific pattern and the dots spread randomly, as well as scattered above and below the 0 number. This means that there is no heteroscedasticity on this regression model, so this model deserves use in research.

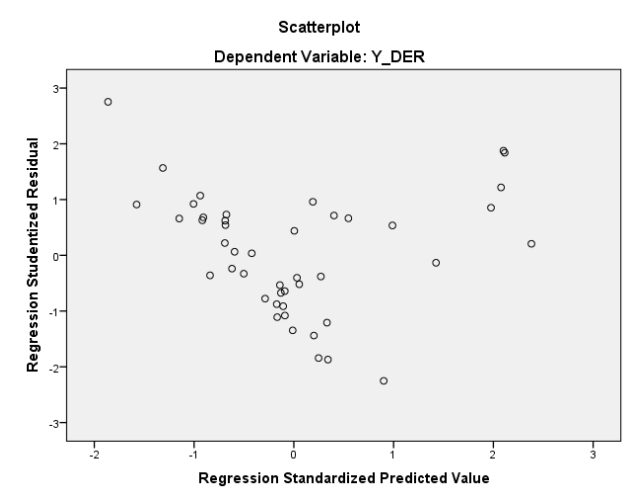

Figure 3. Scatterplot Graph Source : Output IBM SPSS 20.0

\section{Autocorrelation Test}

Autocorrelation is the circumstance in which the regression have a correlation between the residual in the $\mathrm{T}$ period with the residual in the previous period (T-1). A good regression Model is that there is no autocorrelation problem. Decisionmaking has no autocorrelation in this study, our autocorrelation test using Durbin Watson Test and test Run Test with the following test results:

Table 3. Durbin Watson Statistic Test

Model Summary ${ }^{b}$

\begin{tabular}{cccccc}
\hline Model & $\mathbf{R}$ & $\begin{array}{c}\mathbf{R} \\
\text { Square }\end{array}$ & $\begin{array}{c}\text { Adjusted R } \\
\text { Square }\end{array}$ & $\begin{array}{c}\text { Std. Error of } \\
\text { the Estimate }\end{array}$ & $\begin{array}{c}\text { Durbin- } \\
\text { Watson }\end{array}$ \\
\hline 1 &, $803^{\mathrm{a}}$ &, 646 &, 610 &, 66219 & 1,287 \\
\hline
\end{tabular}

a. Predictors: (Constant), X4_SA, X1_ROA, X2_CR, X3_UP

b. Dependent Variable: Y_DER
Based on table Durbin Watson, the value of 1.287 can be explained that the value of Durbin Watson is in $(0<1.287<2.713)$, then there is no positive autocorrelation.

According to Priyatno (2013) Correlation analysis aims to know the relationship of two or more variables. To find out how large the five variables are as follows:

Based on table Coefficient Corellation Test Can be known the correlation of individual variables independent to the dependent variable as:

a. The correlation between profitability to the capital structure if seen from the significance value of 0.000 is smaller than $0.05(0.000<$ 0.05 ) means there is a significant between profitability and capital structure of the correlation coefficient between the profitability and capital structure -0.574 which means that the number indicates that the correlation is negative and strong, meaning that if profitability moves up then the capital structure will decrease.

b. The correlation between liquidity to the capital structure when viewed from a significant value 0,047 is smaller than 0.05 $(0047<0.05)$ meaning there is a significant link between liquidity with capital structure, correlation coefficient- 0.253 being negative. The meaning of direction negative relations is if liquidity rises then the capital structure goes down and vice versa, if the liquidity decreases then capital structure will rise.

c. The correlation between the company size to the capital structure when viewed from a significant value of 0431 is greater than 0.05 $(0431>0.05)$ meaning there is no significant link between the company size to the capital structure.

d. The correlation between asset structure to the capital structure when viewed from a significant value 0.017 is smaller than 0.05 $(0.017<0.05)$ means there is a significant relationship between asset structure and capital structure, correlation coefficient between asset structure and capital structure 
Table 4. Correlation Test

Correlations

\begin{tabular}{lcccccc}
\hline & & Y_DER & X1_ROA & X2_CR & X3_UP & X4_SA \\
\hline \multirow{4}{*}{ Pearson Correlation } & Y_DER & 1,000 &,- 574 &,- 253 &,- 027 &,- 316 \\
& X1_ROA &,- 574 & 1,000 &,- 186 &, 522 &, 203 \\
& X2_CR &,- 253 &,- 186 & 1,000 &,- 497 &,- 310 \\
& X3_UP &,- 027 &, 522 &,- 497 & 1,000 &, 442 \\
& X4_SA &,- 316 &, 203 &,- 310 &, 442 & 1,000 \\
& Y_DER & - &, 000 &, 047 &, 431 &, 017 \\
Sig. (1-tailed) & X1_ROA &, 000 & - &, 110 &, 000 &, 091 \\
& X2_CR &, 047 &, 110 & $\cdot$ &, 000 &, 019 \\
& X3_UP &, 431 &, 000 &, 000 &. &, 001 \\
& X4_SA &, 017 &, 091 &, 019 &, 001 &. \\
& Y_DER & 45 & 45 & 45 & 45 & 45 \\
& X1_ROA & 45 & 45 & 45 & 45 & 45 \\
& X2_CR & 45 & 45 & 45 & 45 & 45 \\
& X3_UP & 45 & 45 & 45 & 45 & 45 \\
& X4_SA & 45 & 45 & 45 & 45 & 45 \\
\hline
\end{tabular}

Source: Output IBM SPSS 20.0

of -0.316 which means the number indicates that the correlation is negative. The higher company's asset structure, company will tend to reduce the company's external funding use.

\section{Analysis of Coefficient Determination (R2)}

Coefficient Determination (R2) Essentially measures the percentage of how far a model is capable of describing the variation of the dependent variable. Coefficient value of determination is between zero and one.

Table 5. Run Test

\begin{tabular}{|c|c|c|c|c|}
\hline \multicolumn{5}{|c|}{ Model Summary $^{b}$} \\
\hline Model & $\mathbf{R}$ & $\begin{array}{c}\text { R } \\
\text { Square }\end{array}$ & $\begin{array}{l}\text { Adjusted R } \\
\text { Square }\end{array}$ & $\begin{array}{l}\text { Std. Error of } \\
\text { the Estimate }\end{array}$ \\
\hline 1 & $803^{a}$ &, 646 & ,610 & 66219 \\
\hline \multicolumn{5}{|c|}{$\begin{array}{l}\text { a. Predictors: (Constant), X4_SA, X1_ROA, X2_CR, X3_UP } \\
\text { b. Dependent Variable: Y_DER } \\
\text { Source: Output IBM SPSS } 20.0\end{array}$} \\
\hline
\end{tabular}

Based on SPSS output in table Coefficient Determination Test (R2 test). Above appears that from the calculation result of Adjust $\mathrm{R}^{2}$ value of 0.610 or $61 \%$. This indicates that $61 \%$ of capital structure variables are affected by the profitability, liquidity, company size and asset structure variables, remaining amount 39\% (100\%-61\%) Influenced by other factors not examined in this study.

\section{Hypothesis Test}

\section{Goodness Fit Test (F test)}

Statistical test F Basically indicates whether the independent variables studied are the return on asset, current ratio, company size and asset structure when included in the model has a simultaneous influence on the dependent variable that is the capital structure. Using a significance rate of $5 \%, \mathrm{~F}$ test is also used to determine whether the model deserves to be used in research.

\begin{tabular}{ccccccc}
\multicolumn{7}{c}{ Table 6. F test } \\
ANOVA $^{\mathbf{a}}$ \\
\hline Model & $\begin{array}{c}\text { Sum of } \\
\text { Squares }\end{array}$ & df & $\begin{array}{c}\text { Mean } \\
\text { Square }\end{array}$ & F & Sig. \\
\hline & Regression & 31,943 & 4 & 7,986 & 18,212 &, $000^{\text {b }}$ \\
\hline $1 \quad$ Residual & 17,540 & 40 &, 438 & & \\
\hline Total & 49,483 & 44 & & & \\
\hline
\end{tabular}

a. Dependent Variable: Y_DER

b. Predictors: (Constant), X4_SA, X1_ROA, X2_CR, X3_UP Source: Output IBM SPSS 20.0

From the statistical test results $\mathrm{F}$ can be seen in table. i.e. the significance value of the known output is $0.000(0.000<0.05)$ then a fit or worthy model used in research.

1. Result of the test on return on asset variable indicates that the significance value 
Table 7. Partial Test ( $\mathrm{t}$ test)

Coefficient $\mathrm{t} \&$ multiple linear regression test

\begin{tabular}{|c|c|c|c|c|c|c|c|c|c|c|}
\hline \multirow[t]{2}{*}{ Mod } & & \multicolumn{2}{|c|}{$\begin{array}{l}\text { Unstandardized } \\
\text { Coefficients }\end{array}$} & \multirow[t]{2}{*}{$\mathbf{t}$} & \multirow[t]{2}{*}{ Sig. } & \multicolumn{3}{|c|}{ Correlations } & \multicolumn{2}{|c|}{$\begin{array}{l}\text { Collinearity } \\
\text { Statistics }\end{array}$} \\
\hline & & B & Std. Error & & & Zero-order & Partial & Part & Tolerance & VIF \\
\hline \multirow{5}{*}{1} & (Constant) & $-1,647$ & 1,774 &,- 928 & ,359 & & & & & \\
\hline & X1_ROA & $-32,342$ & 4,765 & $-6,787$ & 000 &,- 574 &,- 732 & -639 & ,721 & 1,388 \\
\hline & $\mathrm{X} 2$ _CR &,- 053 & ,017 & $-3,050$ & 004 &,- 253 &,- 434 &,- 287 & ,736 & 1,358 \\
\hline & X3_UP & ,200 & ,067 & 2,979 & ,005 &,- 027 & ,426 & ,280 & ,506 & 1,975 \\
\hline & X4_SA & $-2,818$ & 675 & $-4,173$ & 000 &,- 316 &,- 551 &,- 393 & ,794 & 1,260 \\
\hline
\end{tabular}

Source: Output IBM SPSS 20.0

Of $0.000(0.000<0.05)$ indicates that there is a significant influence between the return on asset variable and the capital structure.

1. $\mathrm{T}$ test result on the current ratio variable indicates that the significance value of 0.004 $(0.004<0.05)$ indicates that the current ratio variable has significant effect on the capital structure.

2. Test results in the $t$ test on company size variables indicate that the significance value of $0.005(0.005<0.05)$ indicates that the company size variable has a significant influence on the capital structure.

3. Result on t test of asset structure variable indicates that the significance value of 0.000 $(0.000<0.05)$ indicates that the asset structure variable has a significant influence on the capital structure.

\section{Multiple Linear regression analysis}

Based on table test coefficient $t$ and multiple linear regression above formulated the following equation: The regression equation is interpreted as:

Capital Structure $=-1,647-32,342 \mathrm{ROA}-0,053 \mathrm{CR}$ $+0,200$ CS $-2,818$ AS

1. Constants value is -1.647 . Meaning if the profitability (X1), liquidity (X2), company size (X3), asset structure (X4) value is 1 , then the capital structure $(\mathrm{Y})$ value is -1.647 .

2. Coefficient value of the return on asset (X1) variable is negative, which is-32.342. That means that every increase in return on asset is 1 , then the capital structure will decrease -

\subsection{2.}

3. Current ratio (X2) variable regression coefficient value is negative, which is -0.053 . It means that each increase in current ratio of 1 , then the capital structure will decrease by -0.053 .

4. Company size (X3) has a regression coefficient positive value, which is 0.200 . That means in every company size increase by 1 , then capital structure will increase by 0.200 .

5. value of regression coefficient of asset structure (X4) is negative, which is -2.818 . This means that any increase in the asset structure is 1 , then the capital structure will decrease by -2.818 .

\section{CONCLUSION}

\section{Interpretation Research Result}

A. Profitability Effect on Capital Structure Balancing Theories, according to Fahmi First analysis result is shows significant profitability in the negative direction to the capital structure. It is explained that the company's profitability level is low, the company does not have enough internal funds to meet the company's funding and survival needs. Companies with low profitability may allow capital dependence from outside parties, with low profit rates allowing most corporate funding to be acquired from external funding sources such as debts. Research results are consistent with the research Yodha et al. (2018) stating that the profitability has negative and significant effect on the capital structure. 
B. Current Ratio Effect on Capital Structure

The second analysis results can be seen that the direction of liquidity regression coefficient is negative. High low liquidity significantly affects the capital structure which means the greater the liquidity capability of the company will be increasingly able to repay the debt. The results of the study consistent with Anggraini and Isynuwardana Research (2018) stated that the current ratio was negatively and significantly affect the capital structure.

C. Company Size Effect on Capital Structure

The third analysis results showed significant company size to the capital structure and regression coefficient towards positive. This indicates if there is an increase in the size of the company, there will also increase in the corporate capital structure. Results of this study are consistent with the research of Lasut et al. (2017) stating that the company size is positive and significant to the capital structure.

D. Asset Structure Effect on Capital Structure The results of the fourth analysis show the asset structure significant effect on the capital structure and the regression coefficient in the negative direction which means that if the asset structure increases one unit then the capital structure decreases. When the company has a high fixedasset it will tend to use internal funds compared to external funds in financing its investments. The results of this study were consistent with the research of Tangiduk et al. (2017) which states that the asset structure is negatively and significantly affect the capital structure.

Based on the results of the testing factors affecting the capital structure in the company of the large trade Sub-sector of production goods and consumer goods in the Indonesia Stock
Exchange period 2014-2018, it can be withdrawn as follows:

1. Profitability has negative and significant impact on the capital structure of the company's large trade sub sectors of production goods and consumer goods.

2. Liquidity has negative and significant impact on the capital structure of the company's large trade sub-sectors of production goods and consumer goods.

3. Company size positively and significantly affect the capital structure of the company's large trade sub sectors of production goods and consumer goods.

4. The asset structure is negatively and significantly influential on the capital structure of the company's large trade subsector of production goods and consumer goods.

\section{Managerial Implications}

In this study, especially for the company of large trade sub sectors of production goods and consumer goods in the Indonesia Stock Exchange to reconsider the current capital structure of the company in holding operational activities as well as any factors other than in this research that greatly affects the capital structure of its company, because the return on asset, current ratio, company size and asset structure in this research have a considerable influence on the components of the capital structure. The company is expected to be able to pay attention to the use of debt optimally, because with the addition of too large debts can decrease the financial performance. For the investor to pay attention to the capital structure as a source of funding, whether the company decides to use the source of funds derived from the debt or originating from the internal company is the profit withheld. Investors should choose a company with a smaller level of debt because the greater the debt that the company will use, the greater the risk that investors will bear. 


\section{REFERENCES}

Fahmi, Irham. 2017. Analisis Laporan Keuangan, Cetakan Keempat. Bandung : Alfabeta.

Ghozali, Imam. 2016. Aplikasi Analisis Multivariate Dengan Program SPSS. 23 Ed. 8. Semarang : Badan Penerbit Universitas Diponegoro.

Gunadhi, Putra, 2019. Pengaruh Profitabilitas, Struktur Aset, Likuiditas dan Pertumbuhan Penjualan Terhadap Struktur Modal Perusahaan Makanan dan Minuman di BEI Periode 2015-2017. E-Jurnal Akuntansi, Vol.28, (1) 641 - 668. ISSN.2302-8556.

Harahap, Sofyan Syafitri. 2016. Analisis Kritis Atas Laporan Keuangan. Jakarta : PT Raja Grafindo Persada. Hartijo dan Martono, 2013. Manajemen Keuangan. Edisi Kedua,Yogyakarta : Penerbit Ekonisia.

Hery. 2016. Analisis Laporan Keuangan. Jakarta : PT Grasindo.

Kasmir. 2018. Analisis Laporan Keuangan. Depok : Rajawali Pers.

Munawir. 2014. Analisa Laporan Keuangan. Yogyakarta : Penerbit Liberty.

Rodoni, Ahmad, dkk. 2014. Manajemen Keuangan Modern. Jakarta : Mitra Wacana Media.

Said, Jusmansyah. 2019. Pengaruh Current Ratio, Return On Assets, Total Asset Turnover dan Ukuran Perusahaan Terhadap Struktur Modal Perusahaan Otomotif dan komponen. Jurnal Ekonomika dan Manajemen, Vol. 8. ISSN.2622-6226.

Sartono, Agus. 2015. Manajemen Keuangan Teori dan Aplikasi. Edisi Keempat. Yogyakarta: BPFEYogyakarta.

Stenyverens J.D Lasut, Paulina Van Rate dan Michael Ch. Raintung, Pengaruh Ukuran Perusahaan, Profitabilitas dan Likuiditas terhadap Struktur Modal Perusahaan Otomotif yang terdaftar di Bursa Efek Indonesia Tahun 2012 - 2015. Jurnal EMBA, Vol. 6, No. 1, Januari 2018. ISSN : 2303-1174.

Sutanto, Daniel. 2019. Analisis Pengaruh Current Ratio, Net Profit Margin, Total Asset Turnover dan Ukuran Perusahaan terhadap Struktur Modal Pada Perusahaan Perdagangan Besar Barang Produksi dan Konsumsi yang Terdaftar di Bursa Efek Indonesia Tahun 2013 - 2017. Jurnal Ekonomika dan Manajemen, (1), 59 - 70. ISSN : 2252-6626

Yodha, Adhitya Mahatva, Irdiana et al. Profitabilitas, Likuiditas dan Ukuran Perusahaan Pengaruhnya terhadap Struktur Modal pada Perusahaan Blue Chips di Bursa Efek Indonesia Periode 2011 2016. Jurnal Progress Conference, Vol. 1, No. 1, Agustus 2018. ISSN : 2622-3031.

Santosa, W. S. dan Adji, N. A. (2007) The Investigation of Ground Water Potential by Vertical Electrical Sounding (VES) Approach in Arguni Bay Region, Kaimana Regency, West Papua. Forum Geografi. Vol. 21, No.1, pp. 103-115. 